pÿPrincipals views on changes in the provision of support for learning and schooling in Finland after educational reform

\title{
Pulkkinen, Jonna
}

2019-02

pÿPulkkinen , J , Räikkönen , E , Pirttimaa , R \& Jahnukainen, M 2019 , ' Principals views on changes in the provision of support for learning and schooling in Finland after educational reform ' , Journal of Educational Change , vol. 20 , no. 1 , pp. 137-163 . https://doi.org/10.1007/s10833-018-9334-3

http://hdl.handle.net/10138/308932

https://doi.org/10.1007/s10833-018-9334-3

acceptedVersion

Downloaded from Helda, University of Helsinki institutional repository.

This is an electronic reprint of the original article.

This reprint may differ from the original in pagination and typographic detail.

Please cite the original version. 


\title{
Principals' Views on Changes in the Provision of Support for Learning and Schooling in Finland after Educational Reform
}

\author{
Jonna Pulkkinen, Eija Räikkönen, Raija Pirttimaa and Markku Jahnukainen
}

Recently, the large-scale reforms of special education have been carried out in many countries. This study focuses on the latest Finnish reform of special education in compulsory education. As principals lead educational reforms in schools and their role in the implementation of the reform is significant, the study explores principals' views on the changes in support arrangements after the educational reform. We used latent class analysis to identify the subgroups of principals who share similar views. In addition, we examined the relationship between the subgroups and individual, school, and municipal level factors using multinomial logistic regression analysis. Four subgroups were identified: improved pedagogical support (19\% of principals), stability of support (54\%), increased administrative support (14\%), and weakened support (13\%). Work experience as a principal, school size, schools' resources for special education, and region differentiated these subgroups from one another. Despite nationwide reform, the support arrangements and their changes seem to differ among schools in the opinion of principals. We discuss the implications for the planning and implementation of the educational reforms.

Keywords: academic support services; compulsory education; educational change; principals; reform; special education

\section{Introduction}

In recent years, reforms of special education have been under way in many countries (e.g., Response to Intervention in the United States). These reforms have aimed to secure support for every student and to promote inclusive education. Similarly, the Finnish special education system was reformed in 2011, so that the support model now includes three tiers: general, intensified, and special support (see Finnish National Board of Education, 2014). Although there are similarities in reforms of special education among different countries, they also differ, for example in the political meaning of the models (Jahnukainen \& Itkonen, 2016).

In Finland, one of the essential goals of the reform was to guarantee students' right to timely support. At the same time, however, concern was expressed over the reform's effects on the availability of sufficient support (Education and Culture Committee of the Parliament of 
Finland, 2010; see also Pulkkinen \& Jahnukainen, 2016). Finnish municipalities and schools have been allowed to implement the reform without strict restrictions and to take into consideration the local context when designing support for learning and schooling (Björn et al., 2016; Jahnukainen \& Itkonen, 2016; Pulkkinen \& Jahnukainen, 2016). This kind of autonomy can promote changes at the municipal and school level (Pijl \& Frissen, 2009), but it also likely induces differences among municipalities and schools in supporting students (e.g., Pulkkinen \& Jahnukainen, 2016; Thuneberg et al., 2013). Despite national regulations, the support a student receives can therefore depend on which municipality he or she lives and which school in that particular municipality he or she attends. Furthermore, the changes that the reform of the educational system will inevitably bring about are not necessarily being carried out simultaneously in different schools. For example, the local context, such as the characteristics of the district and the role of the principal in the change, affects the implementation of the reform (Fullan, 2016).

A few studies concerning the latest reform of the Finnish special education system have been published (see Ahtiainen, 2017). Some of them (Pesonen et al., 2015; Pulkkinen \& Jahnukainen, 2016; Thuneberg et al., 2014) have studied the implementation of the reform in municipalities and schools whereas others (Björn et al., 2016; Jahnukainen \& Itkonen, 2016) have compared the Finnish support model with Response to Intervention (RTI) in the US. So far, however, little attention has been paid to the support arrangements or their changes at the school level after the reform and to the factors related to these arrangements or changes in them. Nevertheless, there can be different factors at the individual (e.g., the principals' knowledge of the support system), school (e.g., the resources of the schools), and municipal (e.g., the size of the municipality) levels which relate to how schools arrange support for students. 
Because principals are key actors of educational changes in schools (e.g. Fullan, 2016) and they are in charge of schools' resources (e.g., Jahnukainen, 2015), we chose to study their views on changes in support arrangements. As Fullan (2016) has noted, the implementation of the reform usually concerns three dimensions: materials, teaching approaches, and alteration of beliefs. Here, we focus mainly on how the Finnish special education reform has changed the materials and teaching approaches (i.e., support arrangements). The aim of this study is to explore how the principals of the comprehensive schools view changes in the provision of support arrangements after the educational reform, what kind of subgroups of principals can be identified based on the principals' views, and which factors are related to these subgroups. We identified the subgroups of principals using latent class analysis (LCA) (Vermunt \& Magidson, 2002). The identification of subgroups was based on the principals' views on changes in the support arrangements. LCA enabled us to identify groups of principals who share similar views. This method can be used for the analysis of typologies (McCutcheon, 1987), which, in our study, means that we have empirically identified unobserved latent groups within a set of the observed variables of principals' views. Furthermore, we were interested in the associations among these subgroups and individual, school, and municipal level factors. In order to analyze them, we explored the relationships between group membership and individual, school, and municipal level factors using a multinomial logistic regression analysis.

\section{Reforming Special Education}

Educational change can be seen as a process that takes time (e.g., Fullan, 2016). In Finland, the latest reform of special education in compulsory education (preschool education and Grades 1-9) was put into effect in 2010-2011. In 2010, the funding of special education changed from 
student weighting to being census based (Law 1704/2009; see also Pulkkinen \& Jahnukainen, 2016), and in 2011, a new tiered support model came into effect (Law 642/2010). However, the reform began before legislative changes. The nationwide development project, which aimed to support municipalities and schools in implementing their three-tiered support system, was launched in 2008 (e.g., Ahtiainen, 2017), and most municipalities participated in the project between 2008 and 2012 (Ahtiainen et al., 2012).

Finland has been used as an example of a country in which the education system and educational reforms are based on professional responsibility, trust in teachers, and collaboration at the school and municipal levels (e.g., Hargreaves \& Shirley, 2009; Sahlberg, 2010). This kind of trust is significant when reforming education because it can really motivate school personnel to change practices (Levin \& Fullan, 2008). In addition to the Finnish case, there are also other examples, such as Ontario's special education reform in Canada (see Hargreaves \& Braun, 2012), that have shown how collective professional responsibility can lead to effective educational change. Similarly, in Finland, special education was reformed in collaboration with various stakeholders at different levels of the education system (see Ahtiainen, 2017).

Ahtiainen (2017) has analyzed the key aspects of Fullan and Hargreaves's approaches to educational change, formulated the Fullan-Hargreavesian change model, and applied this model to the latest Finnish special education reform. The model divides educational reform into four categories: entry, objective, dissemination, and impact. According to Ahtiainen (2017), entry includes the justification of the reform (why), whereas objective covers the aims (what) and means (how) of the reform; dissemination refers to how the reform is made accessible and understandable for all stakeholders, and impact refers to the evaluation of progress. 
As Ahtiainen (2017) has described, the why of the Finnish special education reform was defined in the Special Education Strategy of 2007, while the what and how were presented in the Government proposals (Government of Finland 2009a, 2009b; see also Ahtiainen, 2017). The Special Education Strategy (MoE, 2007) expressed the concern about municipal differences in special educational support and emphasized students' right to timely support. Thus, the tiered support model explicitly aimed to improve early intervention and promote inclusive education (Government of Finland 2009a; see also Ahtiainen, 2017; Jahnukainen \& Itkonen, 2016; Pulkkinen \& Jahnukainen, 2016), even though early intervention and inclusive education were already principles in Finnish compulsory education (i.e., prior to the reform) (e.g., Halinen \& Järvinen, 2008).

Furthermore, as described, for example, by Pulkkinen and Jahnukainen (2016), the growth in the number of students in special education was one of the reasons for the aforementioned reforms. Before these reforms, the identification of students with special educational needs had increased in Finland over the years (Kirjavainen et al., 2014b), and, simultaneously, differences among municipalities in the provision of special education had become larger (Kirjavainen et al., 2014a). Consequently, the amended Basic Education Act aimed to assess and arrange support more flexibly by using early forms of support (Ahtiainen, 2017). In addition to the reform of the tiered support system, the funding reform was a means to reduce the number of students in special education (Government of Finland 2009b; see also Pulkkinen \& Jahnukainen, 2016).

According to Fullan (2016), the implementation of the reform is influenced by factors that can be organized into three categories: characteristics of the change (need, clarity, complexity, and quality), local context (district and school level factors), and external factors (government and other agencies). In this study, we focus mainly on factors that are related to local context. As 
Fullan (2016) has stated, districts — so in Finland, municipalities, usually—can develop both capacity and incapacity for change. Studies of the latest Finnish educational reform have shown that there are differences among municipalities and among schools in how they have implemented the three-tier support model (e.g., Pulkkinen \& Jahnukainen, 2016; Thuneberg et al., 2014).

Thuneberg et al. (2014) have studied the reform process related to the three-tiered Finnish model by analyzing municipal documents. According to their study, there were differences among municipalities in adopting the new concepts of the tiered model. Some municipalities used concepts that were compatible with the tiered model (e.g., flexible grouping, co-teaching, and differentiated teaching). Other municipalities, instead, had not adopted the new concepts at all. These included small municipalities and municipalities in which school personnel viewed their prevailing special education system as well-functioning and saw that there was no need to reform it (Thuneberg et al., 2014).

In part, municipal differences can be caused by municipalities' differing financial situations, which, according to Kirjavainen et al. (2014a), have had an effect on special support in Finnish municipalities. According to a study by Pulkkinen and Jahnukainen (2016), local authorities in Finland have made an effort to re-allocate resources for special education differently and more effectively after the reform, but there remain differences among municipalities in how they allocate resources for education. As Levin and Fullan (2008) have stated, effective educational changes demand effective use of resources. Resource allocation or re-allocation is, thus, a way in which district-level leaders can support or alternatively hinder the implementation of the reform (O’Connor \& Freeman, 2012). 
At the school level, the role of principals and teachers in the implementation of the reform is significant (Fullan, 2016). For instance, the various experiences of school personnel can partly explain differences in the implementation of the reform among schools. Both negative and positive experiences from earlier implementations of policy reforms can transfer to later reforms (Fullan, 2016; Pesonen et al., 2015). Furthermore, as Pesonen et al. (2015, p. 174) have stated "varied educational arrangements are due to the way the implementers interpret a policy and make sense of it based on their experiences, values, and professional norms".

As mentioned (above), in the Finnish education system, teachers and schools have significant responsibility for educational reforms (Sahlberg, 2010). Thus, it is obvious that teachers have had key roles in the implementation of the tiered support model in the country. Donnell and Gettinger (2015) have found that teachers are more likely accept a reform if there is congruence among teachers' pedagogical beliefs and the reform. Moreover, they have stated that, in order to have a more positive attitude towards the reform, teachers should have sufficient professional learning opportunities that support them in implementing the reform. Therefore, principals as pedagogical leaders in schools have many chances to affect the reform and they are essential actors in the reform.

The principals can ensure that the use of resources and the organizational culture of the school support implementation of the reform. For example, Castro-Villarreal et al. (2014) found that there should be better communication between the administration and teachers in order to improve the RTI process. Bays and Crockett (2007), instead, have investigated instructional leadership of special education. According to their study, there are some systemic and personal factors which influence instructional leadership. For example, time allotment may be more complicated in larger schools, which in turn affects leadership. Moreover, principals' 
understanding of special education also influences how they lead instructional practices (Bays \& Crockett, 2007). Consequently, in this study, we examine how the principals view the changes in support arrangements after educational reform and if there is a relationship between their views and individual, school, and municipal level factors.

The Finnish Model of Support for Learning and Schooling The current Finnish support model (i.e., Learning and Schooling Support) consists of three tiers. The National Core Curriculum for Basic Education guides municipalities and schools in educational arrangements and instructions (Halinen \& Järvinen, 2008). When reforming the Basic Education Act, the Amendments and Additions to the National Core Curriculum for Basic Education were also released (Finnish National Board of Education, 2010). Although the National Core Curriculum has been renewed again in 2014, the regulations for three-tiered educational support are as before.

According to the National Core Curriculum for Basic Education (Finnish National Board of Education, 2014), general support (Tier 1) is aimed at all students who occasionally need some kind of support (e.g., remedial teaching). When general support is insufficient and a student needs support more regularly, a decision to provide intensified support (Tier 2) is made. This decision is based on pedagogical assessment, and support follows a learning plan. If intensified support, too, is insufficient, a student is entitled to special support (Tier 3). The need for special support has to be assessed and a pedagogical statement has to be made. An individual education plan (IEP) drafted for the student defines the special support arrangements for the student.

There are some arrangements for educational support, mentioned in the National Core Curriculum, which can be included in all three tiers of support. These are co-teaching, flexible 
grouping, remedial teaching, learning plan, part-time special education, special needs assistants, cooperation with families, student welfare team, and differentiation. In this study, we concentrate on the changes in these arrangements. As Fullan (2016) has noted, the implementation of educational change includes at least three dimensions: new or revised materials, new teaching approaches, and alteration of beliefs. The aforementioned arrangements are particularly related to the materials and teaching approaches, even though the use of some of these also requires alteration in teachers' beliefs.

Co-teaching, flexible grouping and differentiation can all be seen as instructional practices in classrooms, and they mostly relate to teachers' work. There is also a relationship among these three so that flexible grouping and differentiation may become easier when teachers are working together (e.g., Friend et al., 2010; Murawski \& Hughes, 2009; Rytivaara, 2011). Co-teaching, along with flexible grouping and differentiation, was an essential part of the nationwide initiative funded by the National Board of Education that aimed to support municipalities in developing new practices (Ahtiainen et al., 2012).

According to a study by Ekstam et al. (2016), in which they investigated support practices in Swedish-speaking schools in Finland, flexible grouping and differentiation are a more common form of support than co-teaching. Similarly, other studies (e.g., Saloviita, 2018; Saloviita \& Takala, 2010; Takala \& Uusitalo-Malmivaara, 2012) have demonstrated that coteaching is rare, especially among classroom teachers and subject teachers in Finnish-speaking schools as well. This may be partly due to a lack of time for planning the lessons together (Takala et al., 2009).

Because co-teaching requires administrative support, for example in facilitating teachers' common planning time (Scruggs et al., 2007), the role of principals in supporting teachers' 
collaboration is essential. Co-teaching is usually seen as collaboration between a general education teacher and a special education teacher (Friend et al., 2010), but in Finland, classroom teachers seem to co-teach more often with other classroom teachers than with special education teachers (Saloviita \& Takala, 2010; Takala \& Uusitalo-Malmivaara, 2012). However, Pesonen et al. (2015) have argued that collaboration between special education teachers and classroom teachers improved along with the reform. On the other hand, Ekstam et al. (2016) found that special education teachers and mathematics teachers reported hardly any changes in collaboration or in other educational practices after the implementation of the tiered support model.

In addition to co-teaching, the tiered support model also calls for collaboration between school personnel and other professionals and parents (Murawski \& Hughes, 2009). In Finland, the National Core Curriculum has required schools, even before the reform, to cooperate with families and municipal social and health authorities (Halinen \& Järvinen, 2008), but in the tiered model, this requirement is more evident. As Thuneberg et al. (2013) have stated, in the tiered support model, multi-professional student welfare work is a significant part of support in all three tiers, and it should be seen as a preventive and school-level early intervention. In addition, when the need for intensified or special support is assessed, the role of multiprofessional collaboration as well as collaboration with families is essential. In Finland, according to Vainikainen et al. (2015), school size and geographical area, for example, affect multiprofessional collaboration (e.g., the frequency of meetings and the availability of the services).

If co-teaching, flexible grouping and differentiation are essential parts of quality pedagogical practices in the classroom, remedial teaching, part-time special education and 
special needs assistants are, above all, arrangements for additional support services. In addition, they are arrangements for which statistics are also compiled by Statistics Finland. For example, in $2012,57 \%$ of the students received remedial teaching, $74 \%$ part-time special education, and 45\% special needs assistance or interpretation services in Tier 2 (Official Statistics of Finland, 2013). By contrast, in Tier 3, 34\% received remedial teaching, 38\% part-time special education, and $55 \%$ special needs assistance or interpretation services.

Of these arrangements, part-time special education has a unique and significant role in the three-tiered support model, because it enables students to be flexibly supported by special education teachers in mainstream teaching groups at all three levels. As Graham and Jahnukainen (2011) have stated, part-time special education has been an exceptional arrangement in the Finnish support system over the decades. It has guaranteed that a student receives additional support in a flexible and timely manner without need for diagnosis (Jahnukainen, 2011). However, according to Pulkkinen and Jahnukainen (2016), resources for part-time special education have been, in the opinion of local authorities, insufficient after the latest reform of special education.

The learning plan is a document that structures the planning and providing of support. As mentioned before, in Tier 2, a learning plan defines arrangements for intensified support, whereas an IEP has to be drafted for students in Tier 3. Furthermore, the National Core Curriculum has mentioned that a learning plan can be drafted for students in Tier 1 even if it is not obligatory. The learning plan is not a new tool for support arrangements. Before the reform, too, all students receiving special support (Tier 3) had an IEP. However, in the tiered support model, the learning plan is required to be drafted for all students in Tier 2 as well. Hence, documentation became a part of all teachers' work in three-tiered model (Thuneberg et al., 
2013). According to Pesonen et al. (2015), there are some signs that the learning plan in the tiered support model has improved the provision of support. However, studies have also shown that the increased documentation and paperwork are seen as a burdensome job in the tiered support model (Castro-Villarreal et al., 2014; Ekstam et al., 2016; Pesonen et al., 2015; Pulkkinen \& Jahnukainen, 2016).

\section{Purpose of the Current Study}

In this study, we focus on the aforementioned arrangements for support and principals' views on changes in them after the educational reform. We chose to study principals' views, for they lead educational reforms in schools. We examine whether there are groups of principals that share similar views on the changes in support arrangements and if some individual, school, and municipal level background factors differentiate these groups of principals from one another.

The research questions of the present study are:

1) How do principals view the changes in support arrangements?

2) Are there subgroups of principals based on their views on changes in support arrangements?

3) How do individual, school, and municipal level factors differentiate the subgroups from one another?

Methods

Data

The participants for this study consisted of principals in Finnish-speaking municipal comprehensive schools. According to Official Statistics of Finland (2012b), in 2012 there were 2 
349 of these schools ( $87 \%$ of all Finnish schools). The special education schools, Swedishspeaking and English-speaking schools or private and state schools were not included in the study. Lists of principals' contact details were acquired from regional state administrative agencies. These lists included all Finnish-speaking schools' principals. Using systematic random sampling, every fourth principal (altogether 600 principals) was selected for this study from the contact detail lists.

The electronic questionnaire was sent to the principals in the autumn of 2012. The questionnaire was re-sent by mail to those participants who did not respond to the electronic questionnaire. Altogether, 348 principals answered the questionnaire. Of these, $12(3.4 \%$ of the available principals) had answered only background questions and one principal reported as being a special school's principal, and thus they were excluded from the sample of this study. After this, the final sample consisted of 335 principals (response rate 56\%). For dependent variables, the proportion of missing values ranged from $1 \%$ to $13.3 \%$. Cases with missing values for all dependent variables $(n=20)$ were not included in the analysis. Hence, the final data used in this study consist of 315 principals ( $52.5 \%$ of the initial sample).

The questionnaire included questions about background of the principals, schools' special education resources, and forms and arrangements of the support for students' education. In the accompanying letter, the principals were informed that register data providing information on municipal variables can be added to the dataset. In this article, only background variables and the variables concerning support arrangements for students' education are analyzed. The results related to the resources and organization of support have been published elsewhere (Pulkkinen \& Jahnukainen, 2015, 2016). 
Table 1 shows information on the background variables of the principals. The work experience as a principal ranged from 0 to 36 years, with a mean of 11.1 years $(S D=8.0)$, and $34.6 \%$ had work experience in special education, too. Most of the principals $(91.7 \%)$ had participated in training concerning tiered support, and $83.8 \%$ reported that his or her school had participated in the initiative related to the reform of the tiered system. Two thirds of the principals worked in primary school (Grades 1-6). Less than half of the principals $(48.6 \%)$ worked in small schools (fewer than 200 students), and most of the principals $(78.1 \%)$ reported that their school's resources for special education are insufficient. The largest proportion of principals $(28.3 \%)$ was from Western and Inland Finland and the smallest proportion of them $(8.9 \%)$ was from the metropolitan area. Most (37.5\%) worked in a municipality in which the population ranged from 10000 to 50 000. By comparing respondents' schools to statistics on all Finnish comprehensive schools, we found that the respondents were relatively representative of the schools and various regions of Finland.

\section{Variables}

The principals were asked to rate different arrangements of support mentioned in the National Core Curriculum for Basic Education as arrangements for supporting students' learning and schooling by stating a question "How is, in your opinion, the condition of the following support arrangements in your school?". The arrangements principals had to assess were as follows: (1) classroom teachers or subjects teachers are co-teaching together, (2) a special education teacher is co-teaching with a classroom teacher or a subject teacher, (3) teaching groups vary flexibly, (4) remedial teaching is arranged for students, (5) a learning plan is drafted for a student, (6) students are receiving part-time special education, (7) special needs assistants are supporting 
students, (8) cooperating with families in order to support students, (9) the student welfare team are seeking solutions on how to support students, and (10) teachers are differentiating their instruction.

The principals rated each arrangement on a scale of $0-4$, where $0=$ Does not exist in our school, 1 = Poor, $2=$ Average, $3=$ Good, and $4=$ Very good. This variable was recoded into a four-level classification by combining categories 0 and 1, that is, if some arrangement does not exist in the school it was interpreted as being poor. According to the National Core Curriculum, each of aforementioned 10 arrangements can be used as a means of all tiers of support. Thus, it can be assumed that all of them should be used in every school and the lack of them can be interpreted as a poor condition. The principals were asked to rate the condition of the support arrangements. They were not asked how often each support arrangements are used in their school or how effective they consider them in supporting learning but rather the availability of these arrangements.

The principals assessed the conditions of the support arrangements in the autumn of 2012 . They had to assess how the arrangements had been before 2011 (i.e., before the changes in legislation) and how they were at the moment (i.e., after the legislative changes in the autumn of 2012 when the principals responded to the questionnaire). We created the new variables of change from each of the ten rated arrangements separately by subtracting before the changes in legislation assessments from after the changes in legislation assessments. These variables were recoded into three categories: $1=$ negative change, $2=$ no change, and $3=$ positive change.

The principals' assessment of the arrangements for support can be related to individual, school or municipal level variables. In this article, the following variables were explored: (1) individual level: work experience as a principal (years), work experience in special education (1 
$=$ yes, $0=$ no $)$, and participation in training concerning support for learning and schooling $(1=$ yes, $0=$ no); (2) school level: school size $(1=$ amount of students less than 200 , and $0=$ amount of students at least 200), grade (Grades 1-6, Grades 1-9, and Grades 7-9), participating in the initiative Action to Develop Intensified and Special Support $(1=$ yes, $0=$ no), and the principal's assessment of the school's resources for special education $(1=$ more resources are needed, $0=$ more resources are not needed), and (3) municipal level: population of the municipal (less than 10000 , at least 10000 but less than 50000 , and at least 50000 ) and geographical regions of Finland.

The division into regions was based on official regional classification. In this classification, Finland has been divided into six regions: Southern, South-Western, Eastern, Western and Inland, Northern Finland and Lapland. This is also how regional state administrative agencies have been divided into regions. In this study, the metropolitan area was separated from Southern Finland into its own group and Northern Finland and Lapland were merged. Population information was obtained from the website of Statistics Finland (Official Statistics of Finland, 2012a).

Analysis

First, principals' views on changes were examined using descriptive statistics. Second, subgroups of principals based on the similarity of their views on the changes in support arrangements were identified using latent class analysis (LCA). LCA is a statistical clustering method that enables the examination of latent structures (i.e., the identification of subgroups) among a set of categorical variables (Vermunt \& Magidson, 2002). In this study, the aforementioned 10 change variables of support arrangements were used to identify groups of principals. Each of the principals belonged to one of a set of $K$ latent groups, and principals who 
belonged to the same group were similar with respect to their views on changes in support arrangements (see Vermunt \& Magidson, 2002).

LCA models with one to seven groups were compared for finding the model that best fits the data. Three different criteria were used to decide the best number of subgroups. First, practical usefulness (i.e., the number of principals in each group) and theoretical interpretativeness of the solution were considered. Second, goodness-of-fit of the competing models with varying number of subgroups were evaluated based on Bayesian information criterion (BIC; Schwartz, 1978), sample-size adjusted BIC (aBIC; Yang, 2006), Lo-MendellRubin adjusted LRT test (LMR; Lo, Mendell \& Rubin, 2001), and parametric bootstrapped likelihood test (BLRT; Nylund et al., 2007).

The model with the lowest information criterion value usually fits the data best. For LMR and BLRT, $p$ values over 0.05 indicate a good fit of the current LCA model (i.e., current number of groups is sufficient) whereas $p$ values below 0.05 indicate that number of groups should be increased by one (Nylund et al., 2007). Several different fit indices should be considered as it has been shown that they do not work well in all situations. Morgan (2014) has shown that BIC tends to underestimate the number of groups and aBIC seems to perform slightly better than BIC does when the sample size is small and there are rare groups. The LMR, in turn, tends to overestimate the number of groups whereas the BLRT usually performs better than the LMR (Nylund et al., 2007).

The third criterion for optimal number of groups was the quality of the identified grouping that can be evaluated based on entropy and average latent class posterior probabilities (AvePP). The entropy illustrates the accuracy of the overall grouping whereas AvePP evaluates how probably a principal ends up in a particular group. Entropy and AvePP values range from 0 to 1 , 
with values close to 1 indicating a distinct grouping (Celeux \& Soromenho, 1996). An AvePP greater than 0.7 for all groups is recommended (Nagin, 2005).

After selecting the best number of groups, we explored the relationship between group membership and individual, school, and municipal level factors with multinomial logistic regression analysis using the automatic three-step method (Asparouhov \& Muthén, 2014). Using this method, the most likely latent group variable obtained from the LCA is regressed on predictor variables while taking into account the measurement error related to the grouping of principals into the latent groups. The predictor variables were treated as auxiliary variables, which means that they did not affect the identification of the final LCA grouping.

The multinomial logistic regression analysis was performed separately for individual, school, and municipal level factors. The results of these analyses are reported in terms of odds ratios (OR) and $95 \%$ confidence intervals $(\mathrm{CI})$. An odds ratio represents a change in the odds of being in a group $j$ (versus being in the reference group), when the value of a particular background factor increases by one unit. An odds ratio greater than one indicates that principals for whom the value of the background factor (e.g., work experience) is one unit higher are more likely in group $j$ than those principals for whom the value of the background factor is one unit lower.

All analyses were conducted using the Mplus statistical package (Version 7.4; Muthén \& Muthén, 1998-2015). The estimator of maximum likelihood with robust standard errors was used. Because the missing data were considered to be missing at random (MAR), full information maximum likelihood procedure was applied in this study, which means that all available data were utilized in the analyses without imputing the missing values. 


\section{Results}

Descriptive statistics in Table 2 illustrate that more than half of the principals assessed the changes in legislation as bringing about positive change in drafting learning plans for students. Most of the principals (range 54\%-78\%) viewed that other support arrangements have not changed after the legislative changes. Part-time special education was the arrangement, which was seen to change the most negatively. Approximately a quarter $(26 \%)$ of the principals assessed this arrangement as being weaker after the legislative changes.

Table 3 presents fit indices and group proportions for one- to seven-group LCA models. Fit statistics showed that the three- and four-group models received support, but the support was not consistent from all of the indices. The values for BIC and the LMR supported the three-group solution, whereas the aBIC value and the BLRT supported the four-group solution. In addition, the indicators of grouping quality were somewhat inconsistent, since entropy supported the fourgroup solution and AvePP the three-group solution. Based on the model fit indices, statistical tests, and clarity of the latent groups, the four-group model was chosen as the final one. This solution was also clearer to interpret.

Figure 1 provides a graphical presentation of conditional probabilities for positive change in the four groups and Table 4 presents conditional probabilities for categories of change among the four latent groups. For the largest group (Group 2, 54\% of principals), "no change" was the most probable option for all but one of the support arrangements. This group was labeled as stability of support. The only arrangement the principals in this group assessed as being better after the legislative changes was drafting a learning plan for a student.

The next largest group (Group 1, 19\% of principals) was labeled as improved pedagogical support. The principals in this group viewed that the forms of support concerning pedagogical 
arrangements (co-teaching between a special education teacher and a classroom teacher or a subject teacher, flexible grouping, drafting a learning plan for a student, student welfare team are seeking solutions to support students, and differentiation) are better after the legislative changes. It seems that this group prefers pedagogical aspects of the reform and views that the positive change after the changes in legislation has been the way to support students more flexibly and individually.

Group 3 (called increased administrative support) included 14\% of the principals. According to this group, the only positive change concerns the learning plan, which has been mentioned in the Basic Education Act and the National Core Curriculum after the changes in legislation. Instead, the principals in this group saw that part-time special education and cooperation with families have changed negatively.

Group 4 (13\% of principals) was named as weakened support. Principals in this group viewed either negative changes or no changes in arrangements of support after the changes in legislation (see Table 4). Most negative changes, according to this group, have occurred in the following arrangements: part-time special education, special needs assistants, cooperation with families, student welfare team, and differentiation. Most of these are arrangements, which also require additional resources or use of teachers' time to cooperate instead of teaching.

The results of multinomial logistic regression analysis indicated that the only statistically significant predictive individual level factor was work experience as a principal (see Table 5). Compared to the improved pedagogical support group, the principals in the stability of support group are those who have more work experience as a principal $(O R=1.07,95 \% \mathrm{CI}[1.01,1.13])$.

Of the school level factors, school size and principals' assessment of the school's resources for special education were related to group membership. Again, compared to the improved 
pedagogical support group, the stability of support group was more likely to include those principals who worked in small schools $(O R=2.72,95 \% \mathrm{CI}[1.02,7.29])$. Compared to the principals in the weakened support group, the principals in the improved pedagogical support group were less likely to work in small schools $(O R=0.14,95 \%$ CI $[0.04,0.53])$ and less likely to want more resources for special education $(O R=0.19,95 \% \mathrm{CI}[0.04,0.98])$.

Of the municipal level factors, region was related to group membership so that, compared to the principals in the improved pedagogical support group, the principals in the stability of support group were more likely to be from Northern Finland $(O R=12.37,95 \%$ CI [1.32, 116.20]) than from the metropolitan area. There was no relationship between group membership and the population of the municipality.

\section{Discussion}

Principals are key actors in educational reforms because they lead changes in schools. In this study, we examined principals' views on the changes in support arrangements after the latest Finnish reform of special education. The purpose was to group the principals on the basis of how they viewed changes in the arrangements for tiered support. In addition, we were interested in whether individual, school, and municipal level factors were related to membership in a particular subgroup. The study showed that principals viewed the changes in arrangements in different ways and that based on those views, four subgroups could be identified according to principals' views, namely, of improved pedagogical support, stability of support, increased administrative support, or weakened support.

The Finnish reform of special education can be regarded as having begun in 2008, after the launch of the Special Education Strategy (see Ahtiainen, 2017), even though the changes in 
legislation and the tiered support model were not implemented until 2011. Therefore, it is not surprising that more than half of the principals were included in Group 2 (stability of support), who saw all arrangements, except drafting a learning plan, as having remained unchanged after the legislative changes. This is probably due to the fact that, in the new legislation, there has been a clear injunction to draft a learning plan for all students in Tier 2 and Tier 3 . For other arrangements, the new regulations are not as explicit as they are for the learning plan.

According to Fullan (2016), the implementation of the reform concerns at least three dimensions: materials, teaching approaches, and alteration of beliefs. The principals associated with Group 1 (improved pedagogical support), which was the second biggest group, saw many positive changes in support arrangements. In particular, the positive changes, in the opinion of this group, seemed to concentrate on those arrangements related to pedagogy and the planning of support. On the other hand, this group's views on changes in the so-called additional support arrangements (i.e., remedial teaching, part-time special education, and special needs assistants) were not as positive as they were on the changes in pedagogical arrangements. This could suggest that, in these schools, the implementation of the reform has been more successful in respect of new teaching approaches than in materials.

The smallest groups were Group 3 (increased administrative support) and Group 4 (weakened support). Principals in these groups saw negative changes in part-time special education and in cooperation with families. The reform has increased obligations related to special education teachers' work in part-time special education (Pulkkinen \& Jahnukainen, 2016) and cooperation with families, which may be reflected by the assessments of principals in these groups. Previous studies (Castro-Villarreal et al., 2014; Ekstam et al., 2016; Pesonen et al., 2015; Pulkkinen \& Jahnukainen, 2016) have demonstrated that the three-tiered support model has 
increased documentation and paper work. This may reduce the time that special education teachers have for instruction, and therefore principals could be critical of the changes in the aforementioned arrangements. However, compared to the principals in Group 4 (weakened support), the principals in Group 3 (the increased administrative support) saw that there was a positive change related to the learning plans. It could be that when compared to Group 4 (weakened support), Group 3 (increased administrative support) views a learning plan not only as bureaucracy but also as a pedagogical tool, thus viewing changes in this arrangement more positively.

The implementation of the reform has been influenced, for example, by factors related to local context, such as district characteristics and the role of principals and teachers (Fullan, 2016). Our results indicated that principals' work experience was related to the subgroups of principals. The principals in Group 2 (stability of support) had more work experience as a principal than the principals in Group 1 (improved pedagogical support) did. It might be that they have a longer perspective on the reform of special education, and therefore, they may view more clearly that the changes in the support system have been under way even before 2011, the year when the amendments to the law came into effect.

Pedagogical arrangements were an essential part of the nationwide initiative, which aimed to support municipalities in developing new practices for tiered support (Ahtiainen et al., 2012). Therefore, it could have been expected that those principals who have participated in training related to the tiered system or whose school has participated in the nationwide reform initiative would include in Group 1 (improved pedagogical support). Our results, however, do not support this. This may be due to the fact that most of the principals and schools had participated in 
training or in the initiative, thus principals did not differ much from one another in respect to these variables.

Of the school and district level factors, school size, school resources for special education, and region were related to the subgroups of principals. Compared to Group 1 (improved pedagogical support) there were more of the principals in Group 2 (stability of support) in small schools, and they worked more often in municipalities in Northern Finland than in metropolitan area. In this study, we examined the relationship between school level and municipal level factors separately. In our data, 53\% of Northern Finland's schools were small schools, whereas only $21 \%$ of the metropolitan area's school were small schools. Because there were more small schools in Northern Finland than in the metropolitan area, the difference between these two regions could be partly explained by the larger proportion of the small schools in Northern Finland.

Thuneberg et al. (2014) have shown that small municipalities, where small schools are most typically located ( $47 \%$ of small schools in our data were in municipalities with less than 10000 residents), have slowly adopted concepts of the three-tiered model. Hence, this fact might explain why principals in small schools were included more often in Group 2 (stability of support), even though the size of the municipality was found not to be directly related to subgroups when analyzing the relationship between municipal level factors and group membership. On the other hand, pedagogical arrangements could be, to start with, more flexible in small schools, as Kalaoja and Pietarinen (2009) have suggested.

There is more personnel in large schools, which may enable more variability in pedagogical support. For example, Vainikainen et al. (2015) have indicated that school size affects multiprofessional collaboration so that meetings of the student welfare team are less 
regular in small schools, especially in less urban areas of Finland. Moreover, some pedagogical arrangements, such as co-teaching or flexible grouping, may be difficult to put into practice in small schools where there are only a few teachers and perhaps no special education teachers at all. On the other hand, the principals in Group 4 (weakened support) had often assessed most of the arrangements to be good or very good before the reform. Although they viewed the negative changes in the arrangements, most of them did not view them as being poor. Hence, it seems that it is not the tiered support that Group 4 are criticizing but the current resources for schools to arrange such support. More research, however, is needed to better understand the relationship between schools' resources and principals' views on changes.

This study has some limitations. First, the data were gathered in 2012, over a year after the changes in legislation came into effect. Thus, the principals have responded retrospectively to the questions concerning support arrangements before the legislative changes. It is probable that this has an effect on principals' views. Although our purpose was not to study the quality of support arrangements before or after the legislative changes but the perceived changes in support arrangements, it is obvious that views on how arrangements were before the changes in legislation have an effect on how they have been viewed after the changes in legislation. On the other hand, when assessing at the same time how arrangements were before and after the legislative changes, the principals may assess, if unintentionally, the changes in these arrangements, too. This can be an advantage for our study because our purpose was, primarily, to examine principals' views on changes in support arrangements.

Second, in this study principals were asked to assess the condition of the support arrangements on a scale of ranging from poor to very good. They were not asked how frequently these arrangements are used in their school or how effective they see them to be in supporting 
students' learning and schooling. Hence, the changes can only be interpreted as principals' subjective opinion concerning the condition of the support, not the objective reporting of frequency or effectiveness of the support arrangements.

Third, missing values on dependent variables seemed to be related to the principals' assessment of a school's resources for special education. Therefore, the results of the association between a school's resource and the groups of principals should be interpreted with caution. In addition, variables such as the number of teachers and special education teachers per student or the average class size of a school could be better for measuring a school's resources. Yet, these issues were not asked about in our questionnaire.

Fourth, it should be remembered that LCA explores the response pattern of principals. Thus, the meaning of latent groups or their labels are primarily researchers' interpretation of this pattern. LCA, however, provides a method to group principals based on their views on changes in different arrangements, and therefore, differences in views can be analyzed.

\section{Conclusions}

Recent large-scale reforms of special education, both in Finland and elsewhere, have aimed to secure timely and sufficient support for every student. As Ahtiainen (2017) has described, the what (aims) and how (means) of the Finnish reform relate to a student's right to early support and to the re-organization of the support system so that support can be arranged flexibly. This study concentrated especially on the how of the reform. It showed that after the latest Finnish reform of special education the changes in the support arrangements have not been, in the opinion of principals, only positive in the schools. Although the aim of the Finnish reform was to secure all students the support they need, it seems that some arrangements, especially those 
calling for additional resources, have changed negatively in some schools. Since resources and their allocation are essential in the implementation of the reform (e.g., Levin \& Fullan, 2008; O’Connor \& Freeman, 2012), they should also be taken into consideration early on when planning the how of the reform.

Despite nationwide regulations, the support arrangements and their changing after the educational reform can differ a lot among schools, as our study has shown. It seems that schools arrange the support regulated in the National Core Curriculum in their own way depending on the ability of each school or municipality. This result supports the findings of previous studies (e.g., Thuneberg et al., 2014; Vainikainen et al., 2015). The flexibility in the implementation of educational reform can be seen as a good thing, as local context varies (see e.g., Hargreaves \& Braun, 2012). Hence, the differences in support arrangements can be acceptable if all students receive sufficient support and this support is efficient enough regardless of how this support has been arranged. Yet, if differences in the support arrangements among schools affect students' learning, more regulations of the support are needed in order to guarantee all students equal opportunities in education. This study did not measure if there are differences among schools in the efficiency of support. Therefore, further studies regarding the impact of the differences in support arrangements would be worthwhile. However, our study suggests the need, when planning and implementing large-scale educational reforms, to take into account the differences among schools and the variety in their practices, resources and abilities for reform.

Fullan (2016) has stated that effective principals are "lead learners" who participate as a learner with teachers and, in addition, collaborate at the district level. Thus, the role of principals regarding the implementation of educational reforms is significant. Because Finnish schools have great autonomy in educational reforms (Sahlberg, 2010), the role of principals and their views on 
the reform, as well as the schools' educational practices, are even more significant. When principals allocate resources in schools, they should not view the educational reform from an administrative perspective only but also from a pedagogical perspective, so that the use of resources supports the pedagogical aims of the reform. Thus, it should be ensured that principals and other administrative personnel receive, for example, in-service training so that they are informed enough of the pedagogical aspects of the reform. However, as Fullan (2016) has noted, principals usually have little preparation for educational reforms and their leading.

In this study, we were unable to examine how principals' earlier experiences of reforms might have affected their views. As, for example, Fullan (2016) and Pesonen et al. (2015) have suggested, both negative and positive experiences from earlier reforms can transfer to later reforms. Further research on this question would be worthwhile. Similarly, more information on how each of the support arrangements has been implemented in schools following the Finnish special education reform would be useful, as well as on the alteration of beliefs, which is one dimension in implementing educational change (see Fullan, 2016). Since our data were gathered in 2012 and educational changes take time, a renewed data collection that, in addition to support arrangements, focuses on the aforementioned questions and how well the aims (what) of the Finnish reform have been achieved would be of great help. 


\section{References}

Ahtiainen, R. (2017). Shades of change in Fullan's and Hargreaves 's models: Theoretical change perspectives regarding Finnish special education reform. Doctoral dissertation, University of Helsinki.

Ahtiainen, R., Beirad, M., Hautamäki, J., Hilasvuori, T., Lintuvuori, M., Thuneberg, H., Vainikainen, M.-P., \& Österlund, I. (2012). Tehostettua ja erityistä tukea tarvitsevien oppilaiden opetuksen kehittäminen 2007-2011. Kehittävän arvioinnin loppuraportti [Developing the instruction of students in need of intensified and special support in 20072011. The final report of developing evaluation] (Research reports of the Ministry of Education and Culture No. 5). Retrieved from Ministry of Education and Culture website: http://www.minedu.fi/export/sites/default/OPM/Julkaisut/2012/liitteet/okm05.pdf

Asparouhov, T., \& Muthén, B. (2014). Auxiliary variables in mixture modeling: Three-step approaches using Mplus. Structural Equation Modeling: A Multidisciplinary Journal, 21(3), 329-341. doi: 10.1080/10705511.2014.915181

Bays, D. A., \& Crockett, J. B. (2007). Investigating instructional leadership for special education. Exceptionality, 15(3), 143-161. doi: 10.1080/09362830701503495

Björn, P. M., Aro, M. T., Koponen, T. K., Fuchs, L. S., \& Fuchs, D. H. (2016). The many faces of special education within RTI Frameworks in the United States and Finland. Learning Disability Quarterly, 39(1), 58-66. doi: 10.1177/0731948715594787

Castro-Villarreal, F., Rodriguez, B. J., \& Moore, S. (2014). Teachers' perceptions and attitudes about Response to Intervention (RTI) in their schools: A qualitative analysis. Teaching and Teacher Education, 40, 104-112. doi: 10.1016/j.tate.2014.02.004

Celeux, G., \& Soromenho, G. (1996). An entropy criterion for assessing the number of clusters in a mixture model. Journal of Classification, 13, 195-212. doi:10.1007/BF01246098

Donnell, L. A., \& Gettinger, M. (2015). Elementary school teachers' acceptability of school reform: Contribution of belief congruence, self-efficacy, and professional development. Teaching and Teachers Education, 51,47-57. doi: 10.1016/j.tate.2015.06.003

Education and Culture Committee of the Parliament of Finland 2010. Sivistysvaliokunnan mietintö 4/2010 vp [Report of the Education and Culture Committee of Parliament]. http://www.eduskunta.fi/faktatmp/utatmp/akxtmp/sivm_4_2010_p.shtml 
Ekstam, U., Linnanmäki, K., \& Aunio, P. (2015). Educational support for low-performing students in mathematics: the three-tier support model in Finnish lower secondary schools. European Journal of Special Needs Education, 30(1), 75-92. doi: 10.1080/08856257.2014.964578

Finnish National Board of Education. (2010). Perusopetuksen opetussuunnitelman perusteiden muutokset ja täydennykset 2010 [Amendments and Additions to the National Core Curriculum for Basic Education 2010]. Retrieved from:

http://www.oph.fi/download/132882_Perusopetuksen_opetussuunnitelman_perusteiden_m uutokset_ja_taydennykset2010.pdf

Finnish National Board of Education. (2014). Perusopetuksen opetussuunnitelman perusteet 2014 [The National Core Curriculum for Basic Education 2014]. Retrieved from: http://www.oph.fi/download/163777_perusopetuksen_opetussuunnitelman_perusteet_2014 .pdf

Friend, M., Cook, L., Hurley-Chamberlain, D., \& Shamberger, C. (2010). Co-teaching: An illustration of the complexity of collaboration in special education. Journal of Educational and Psychological Consultation, 20(1), 9-27. doi:10.1080/10474410903535380

Fullan, M. (2016). The NEW meaning of educational change (Fifth edition.). New York, NY: Teachers College Press.

Government of Finland 2009a. Hallituksen esitys laiksi perusopetuslain muuttamisesta 109/2009. [Government proposal for the Act to amend the Basic Education Act]. http://www.finlex.fi/fi/esitykset/he/2009/20090109

Government of Finland 2009b. Hallituksen esitys Eduskunnalle laiksi kunnan peruspalvelujen valtionosuudesta, laiksi opetus- ja kulttuuritoimen rahoituksesta ja laeiksi eräiden niihin liittyvien lakien muuttamisesta 174/2009. [Government proposal for the Act on government transfers for local basic services, for the Act on the Financing of Education and Culture and for the Acts to amend some acts related to them]. http://www.finlex.fi/fi/esitykset/he/2009/20090174

Graham, L. J., \& Jahnukainen, M. (2011). Wherefore art thou, inclusion? Analysing the development of inclusive education in New South Wales, Alberta and Finland. Journal of Education Policy, 26(2), 263-288. doi: 10.1080/02680939.2010.493230 
Halinen, I., \& Järvinen, R. (2008). Towards inclusive education: the case of Finland. Prospects, 38, 77-97. doi 10.1007/s11125-008-9061-2

Hargreaves, A., \& Braun, H. (2012). Leading for all: Final report of the review of the development of essential for some, good for all: Ontario's strategy for special education reform devised by the Council of Directors of Education. Toronto, Ontario: Council of Directors of Education.

Hargreaves, A., \& Shirley, D. (2009). The Fourth Way: The Inspiring Future for Educational Change. Thousand Oaks: Corwin.

Jahnukainen, M. (2011). Different Strategies, Different Outcomes? The History and Trends of the Inclusive and Special Education in Alberta (Canada) and in Finland. Scandinavian Journal of Educational Research, 55(5), 489-502. doi: 10.1080/00313831.2010.537689

Jahnukainen, M. (2015). Inclusion, Integration, or What? A Comparative Study of the School Principals' Perceptions of Inclusive and Special Education in Finland and in Alberta, Canada. Disability \& Society, 30(1), 59-72. doi:10.1080/09687599.2014.982788

Jahnukainen, M., \& Itkonen, T. (2016). Tiered intervention: history and trends in Finland and United States. European Journal of Special Needs Education, 31(1), 140-150. doi: $10.1080 / 08856257.2015 .1108042$

Kalaoja, E., \& Pietarinen, J. (2009). Small rural primary schools in Finland: A pedagogically valuable part of the school network. International Journal of Educational Research, 48, 109-116. doi: 10.1016/j.ijer.2009.02.003

Kirjavainen, T., Pulkkinen, J., \& Jahnukainen, M. (2014a). Erityisoppilaiden osuuksien kuntakohtaiseen vaihteluun vaikuttaneet tekijät vuosina 2001-2010 [Factors affecting municipal variation in the share of students with special education needs in 2001-2010]. Yhteiskuntapolitiikka, 79(6), 619-630.

Kirjavainen, T., Pulkkinen, J., \& Jahnukainen, M. (2014b). Perusopetuksen erityisopetusjärjestelyt eri ikäryhmissä vuosina 2001-2010 [Special education arrangements in basic education for different age cohorts in years 2001-2010]. Kasvatus [The Finnish Journal of Education], 45(2), 152-166.

Law 1704/2009. Laki kunnan peruspalvelujen valtionosuudesta [Act on Government Transfers for Local Basic Services]. http://www.finlex.fi/fi/laki/smur/2009/20091704. 
Law 642/2010. Laki perusopetuslain muuttamisesta [Act on the Amendment of the Basic Education Act]. http://www.finlex.fi/fi/laki/alkup/2010/20100642.

Levin, B., \& Fullan, M. (2008). Learning about system renewal. Educational management administration \& leadership, 36(2), 289-303.

Lo, Y., Mendell, N. R., \& Rubin, D. B. (2001). Testing the number of components in a normal mixture. Biometrika, 88(3), 767-778.

McCutcheon, A. L. (1987). Latent class analysis. Thousand Oaks: SAGE Publications.

MoE (2007). Erityisopetuksen strategia [Special Education Strategy]. Reports of the Ministry of Education 47.

Morgan, G. B. (2014). Mixed mode latent class analysis: An examination of fit index performance for classification. Structural Equation Modeling: A Multidisciplinary Journal, 22(1), 76-86. doi: 10.1080/10705511.2014.935751

Murawski, W. W., \& Hughes, C. E. (2009). Response to intervention, collaboration, and coteaching: A logical combination for successful systemic change. Preventing School Failure: Alternative Education for Children and Youth, 53(4), 267-277. doi: 10.3200/PSFL.53.4.267-277

Muthén, L.K., \& Muthén, B.O. (1998-2015). Mplus User's Guide (7th ed.). Los Angeles, CA: Muthén \& Muthén.

Nagin, D. S. (2005). Group-based modeling of development. Cambridge, MA: Harvard University Press.

Nylund, K. L., Asparouhov, T., \& Muthén, B. O. (2007). Deciding on the number of classes in latent class analysis and growth mixture modeling: A Monte Carlo simulation study. Structural Equation Modeling: A Multidisciplinary Journal, 14(4), 535-569. doi: $10.1080 / 10705510701575396$

O’Connor, E. P., \& Freeman, E. W. (2012). District-level considerations in supporting and sustaining RtI implementation. Psychology in the Schools, 49(3), 297-310. doi: $10.1002 /$ pits. 21598

Official Statistics of Finland. (2012a). Population structure [e-publication]. Helsinki: Statistics Finland. Retrieved from: http://www.stat.fi/til/vaerak/2012/vaerak_2012_2013-0322_tie_001_en.html 
Official Statistics of Finland. (2012b). Providers of education and educational institutions [epublication]. Helsinki: Statistics Finland. Retrieved from:

http://www.stat.fi/til/kjarj/2012/kjarj_2012_2013-02-19_tie_001_en.html

Official Statistics of Finland. (2013). Special education [e-publication]. Helsinki: Statistics

Finland. Retrieved from: http://www.stat.fi/til/erop/2012/erop_2012_2013-06-

12_tie_001_en.html

Pesonen, H., Itkonen, T., Jahnukainen, M., Kontu, E., Kokko, T., Ojala, T., \& Pirttimaa, R. (2015). The Implementation of New Special Education Legislation in Finland. Educational Policy, 29(1), 162 -178. doi: 10.1177/0895904814556754

Pijl, S. J., \& Frissen, P. H. A. (2009). What policymakers can do to make education inclusive. Educational Management Administration \& Leadership, 37(3), 366-377. doi: $10.1177 / 1741143209102789$

Pulkkinen, J., \& Jahnukainen, M. (2015). Erityisopetuksen järjestäminen ja resurssit kunnissa lakimuutosten jälkeen [The organization and resources of special education in municipalities after legislative reforms]. In M. Jahnukainen, E. Kontu, H. Thuneberg, \& M.-P. Vainikainen (Eds.), Erityisopetuksesta oppimisen ja koulunkäynnin tukeen [From Special Education to Support for Learning and Schooling] (pp. 79-105). The Finnish Educational Research Association.

Pulkkinen, J., \& Jahnukainen, M. (2016). Finnish reform of the funding and provision of special education: the views of principals and municipal education administrators. Educational Review, 68(2), 171-188. doi: 10.1080/00131911.2015.1060586

Rytivaara, A. (2011). Flexible grouping as a means for classroom management in a heterogeneous classroom. European Educational Research Journal, 10(1), 118-128. doi: 10.2304/eerj.2011.10.1.118

Sahlberg, P. (2010). Rethinking accountability in a knowledge society. Journal of Educational Change, 11, 45-61. doi: 10.1007/s10833-008-9098-2

Saloviita, T. (2018). How common are inclusive educational practices among Finnish teachers? International Journal of Inclusive Education, 22(5), 560-575. doi: 10.1080/13603116.2017.1390001 
Saloviita, T., \& Takala, M. (2010). Frequency of co-teaching in different teacher categories.

European Journal of Special Needs Education, 25(4), 389-396. doi: $10.1080 / 08856257.2010 .513546$

Schwartz, G. (1978). Estimating the dimension of a model. The Annals of Statistics, 6, 461-464.

Scruggs, T. E., Mastropieri, M. A., \& McDuffie, K. A. (2007). Co-teaching in inclusive classrooms: A metasynthesis of qualitative research. Exceptional Children, 73(4), 392416. doi: $10.1177 / 001440290707300401$

Takala, M., Pirttimaa, R., \& Törmänen, M. (2009). Inclusive special education: the role of special education teachers in Finland. British Journal of Special Education, 36(3), 162173. doi: 10.1111/j.1467-8578.2009.00432.x

Takala, M., \& Uusitalo-Malmivaara, L. (2012). A one-year study of the development of coteaching in four Finnish schools. European Journal of Special Needs Education, 27(3), 373-390. doi: 10.1080/08856257.2012.691233

Thuneberg, H., Hautamäki, J., Ahtiainen, R., Lintuvuori, M., Vainikainen, M.-P., \& Hilasvuori, T. (2014). Conceptual change in adopting the nationwide special education strategy in Finland. Journal of Educational Change, 15, 37-56. doi: 10.1007/s10833-013-9213-x

Thuneberg, H., Vainikainen, M.-P., Ahtiainen, R., Lintuvuori, M., Salo, K., \& Hautamäki, J. (2013). Education is special for all: The Finnish support model. Gemeinsam Leben, 2, 6778 .

Vainikainen, M.-P., Thuneberg, H., Greiff, S., \& Hautamäki, J. (2015). Multiprofessional collaboration in Finnish schools. International Journal of Educational Research, 72, 137 148. doi: 10.1016/j.ijer.2015.06.007

Vermunt, J. K., \& Magidson, J. (2002). Latent class cluster analysis. In J. A. Hagenaars, \& A. L. McCutcheon (Eds.), Applied latent class analysis (pp. 89-106). New York: Cambridge University Press.

Yang, C. (2006). Evaluating latent class analyses in qualitative phenotype identification. Computational Statistics \& Data Analysis, 50, 1090-1104. doi:10.1016/j.csda.2004.11.004 
Figure 1. Conditional Probabilities of Positive Change in the Four Groups.

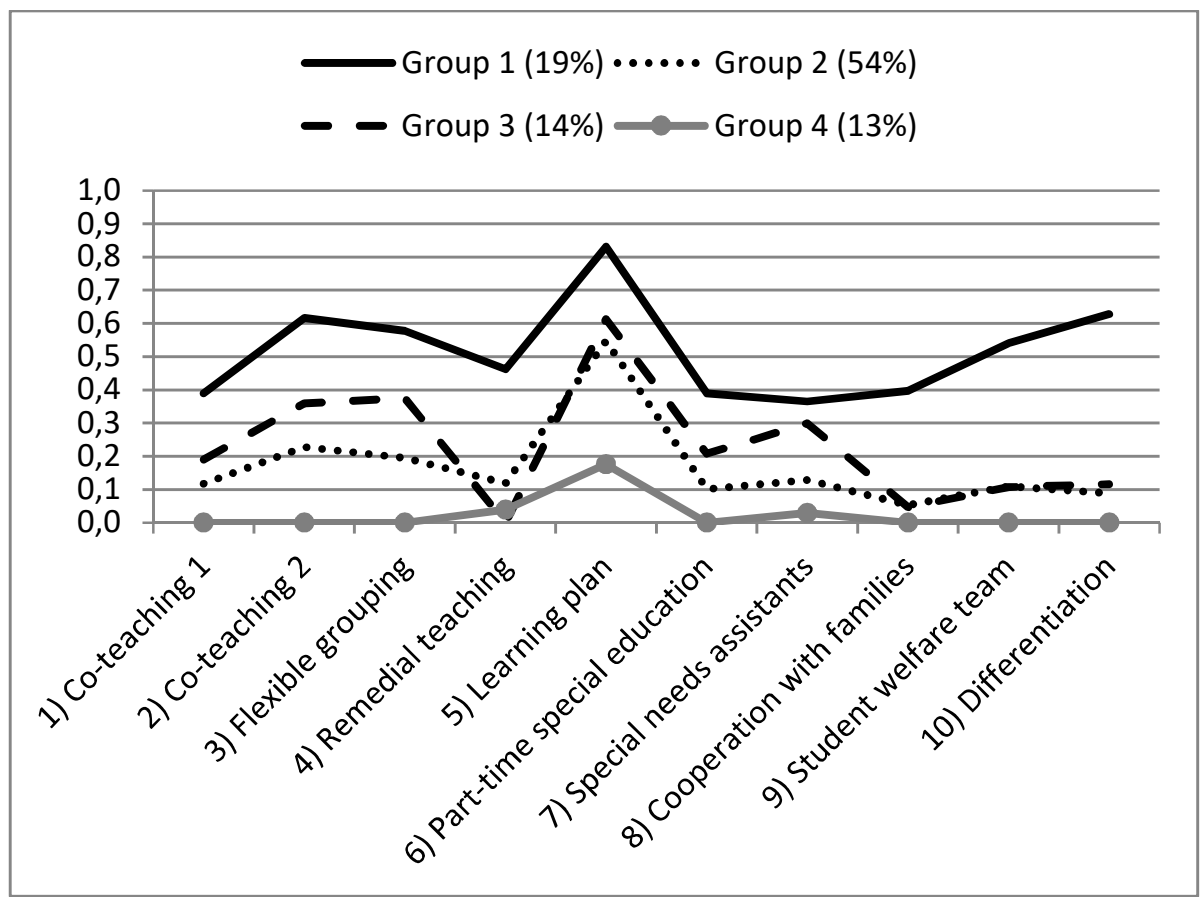


Table 1. Descriptive Statistics for Background Variables $(N=315)$

\begin{tabular}{|c|c|c|}
\hline Variable & $\mathrm{M}(\mathrm{SD})$ & $\%$ \\
\hline Work experience as a principal (years; range $0-36$ years) & $11.1(8.0)$ & \\
\hline \multicolumn{3}{|l|}{ Work experience in special education } \\
\hline No & & 64.8 \\
\hline Yes & & 34.6 \\
\hline Missing & & 0.6 \\
\hline \multicolumn{3}{|l|}{$\begin{array}{l}\text { Participation in training concerning support for learning and } \\
\text { schooling }\end{array}$} \\
\hline No & & 7.6 \\
\hline Yes & & 91.7 \\
\hline Missing & & 0.6 \\
\hline \multicolumn{3}{|l|}{ School size } \\
\hline Amount of students at least 200 & & 51.4 \\
\hline Amount of students less than 200 & & 48.6 \\
\hline \multicolumn{3}{|l|}{ Grade } \\
\hline Grades $1-6$ & & 64.4 \\
\hline Grades $1-9$ & & 20.6 \\
\hline Grades 7-9 & & 14.9 \\
\hline \multicolumn{3}{|l|}{$\begin{array}{l}\text { Participating in the initiative Action to Develop Intensified } \\
\text { and Special Support }\end{array}$} \\
\hline No & & 15.2 \\
\hline Yes & & 83.8 \\
\hline Missing & & 1.0 \\
\hline \multicolumn{3}{|l|}{$\begin{array}{l}\text { Principal's assessment of the school's resources for special } \\
\text { education }\end{array}$} \\
\hline More resources are not needed & & 21.9 \\
\hline More resources are needed & & 78.1 \\
\hline \multicolumn{3}{|l|}{ Region } \\
\hline Metropolitan area & & 8.9 \\
\hline Southern & & 21.9 \\
\hline South-Western & & 12.4 \\
\hline Eastern & & 11.4 \\
\hline Western and Inland & & 28.3 \\
\hline Northern & & 17.1 \\
\hline \multicolumn{3}{|l|}{ Population } \\
\hline $50000-$ & & 29.2 \\
\hline $10000-49999$ & & 37.5 \\
\hline 0-9999 & & 33.3 \\
\hline
\end{tabular}


Table 2. Principals' Assessments of the Changes in the Support Arrangements

\begin{tabular}{|c|c|c|c|c|c|}
\hline & \multicolumn{2}{|c|}{ Before Year 2011} & \multicolumn{2}{|c|}{ Year 2012} & \multirow{2}{*}{$\begin{array}{c}\text { Change } \\
\%\end{array}$} \\
\hline & $\begin{array}{c}\text { Poor } \\
\%\end{array}$ & $\begin{array}{c}\text { Very Good } \\
\%\end{array}$ & $\begin{array}{c}\text { Poor } \\
\%\end{array}$ & $\begin{array}{c}\text { Very Good } \\
\%\end{array}$ & \\
\hline Co-teaching $1^{\mathrm{a}}$ & 68.9 & 4.1 & 57.8 & 3.2 & \\
\hline Negative change & & & & & 3.8 \\
\hline No change & & & & & 78.4 \\
\hline $\begin{array}{l}\text { Positive change } \\
\text { Missing }\end{array}$ & & & & & $\begin{array}{c}16.8 \\
1.0\end{array}$ \\
\hline Co-teaching $2^{\mathrm{b}}$ & 49.5 & 5.4 & 35.9 & 5.4 & \\
\hline Negative change & & & & & 8.3 \\
\hline No change & & & & & 60.6 \\
\hline $\begin{array}{l}\text { Positive change } \\
\text { Missing }\end{array}$ & & & & & $\begin{array}{c}29.5 \\
1.6\end{array}$ \\
\hline Flexible grouping & 33.0 & 10.2 & 22.5 & 12.1 & \\
\hline Negative change & & & & & 13.3 \\
\hline No change & & & & & 56.2 \\
\hline Positive change & & & & & 27.0 \\
\hline Missing & & & & & 3.5 \\
\hline Remedial teaching & 4.4 & 21.9 & 3.2 & 21.6 & \\
\hline Negative change & & & & & 19.4 \\
\hline No change & & & & & 58.4 \\
\hline Positive change & & & & & 15.2 \\
\hline Missing & & & & & 7.0 \\
\hline Learning plan & 29.2 & 8.3 & 3.5 & 24.8 & \\
\hline Negative change & & & & & 4.4 \\
\hline No change & & & & & 37.1 \\
\hline Positive change & & & & & 54.9 \\
\hline Missing & & & & & 3.5 \\
\hline $\begin{array}{l}\text { Part-time special } \\
\text { education }\end{array}$ & 4.8 & 20.3 & 5.4 & 13.0 & \\
\hline Negative change & & & & & 25.7 \\
\hline No change & & & & & 53.7 \\
\hline $\begin{array}{l}\text { Positive change } \\
\text { Missing }\end{array}$ & & & & & $\begin{array}{l}15.6 \\
5.1\end{array}$ \\
\hline Special needs assistants & 9.8 & 16.2 & 10.8 & 21.6 & \\
\hline Negative change & & & & & 15.9 \\
\hline No change & & & & & 59.4 \\
\hline Positive change & & & & & 18.1 \\
\hline Missing & & & & & 6.7 \\
\hline $\begin{array}{l}\text { Cooperation with } \\
\text { families }\end{array}$ & 2.2 & 29.8 & 0.3 & 25.7 & \\
\hline Negative change & & & & & 17.1 \\
\hline No change & & & & & 64.4 \\
\hline Positive change & & & & & 10.8 \\
\hline Missing & & & & & 7.6 \\
\hline
\end{tabular}




\begin{tabular}{|c|c|c|c|c|c|}
\hline Student welfare team & 5.4 & 27.9 & 2.2 & 31.1 & \\
\hline Negative change & & & & & 14.6 \\
\hline No change & & & & & 59.0 \\
\hline $\begin{array}{l}\text { Positive change } \\
\text { Missing }\end{array}$ & & & & & $\begin{array}{c}16.8 \\
9.5\end{array}$ \\
\hline Differentiation & 11.4 & 13.3 & 3.8 & 12.7 & \\
\hline Negative change & & & & & 13.3 \\
\hline No change & & & & & 61.9 \\
\hline Positive change & & & & & 18.1 \\
\hline Missing & & & & & 6.7 \\
\hline
\end{tabular}

Note. ${ }^{\mathrm{a}}$ Classroom teachers or subjects teachers are co-teaching together. ${ }^{\mathrm{b}} \mathrm{A}$ special education teacher is co-teaching with a classroom teacher or a subject teacher. 
Table 3. Fit Indices for Latent Class Analyses and Group Proportions

\begin{tabular}{|c|c|c|c|c|c|c|}
\hline $\begin{array}{l}\text { No. of } \\
\text { groups }\end{array}$ & BIC & aBIC & $\begin{array}{c}\text { LMR } \\
(p)\end{array}$ & $\begin{array}{l}\text { BLRT } \\
\text { (p) }\end{array}$ & Entropy & Group proportions \\
\hline 1 & 5254.384 & 5190.950 & & & & $100 \%$ \\
\hline 2 & 5122.823 & 4992.782 & $\begin{array}{l}250.294 \\
(\mathrm{p}=.063)\end{array}$ & $\begin{array}{l}-2569.666 \\
(\mathrm{p}=.000)\end{array}$ & 0.690 & $6 \% / 34 \%$ \\
\hline 3 & 5106.799 & 4910.152 & $\begin{array}{l}135.705 \\
(\mathrm{p}=.001)\end{array}$ & $\begin{array}{l}-2443.484 \\
(\mathrm{p}=.000)\end{array}$ & 0.741 & $21 \% / 51 \% / 28 \%$ \\
\hline 4 & 5164.553 & 4901.300 & $\begin{array}{c}62.532 \\
(\mathrm{p}=.584)\end{array}$ & $\begin{array}{l}-2375.070 \\
(\mathrm{p}=.000)\end{array}$ & 0.759 & $19 \% / 54 \% / 14 \% / 13 \%$ \\
\hline 5 & 5238.799 & 4908.940 & $\begin{array}{c}46.176 \\
(p=.027)\end{array}$ & $\begin{array}{l}-2343.545 \\
(\mathrm{p}=.103)\end{array}$ & 0.787 & $19 \% / 28 \% / 11 \% / 32 \% / 10 \%$ \\
\hline 6 & 5317.869 & 4921.403 & $\begin{array}{c}41.392 \\
(p=.760)\end{array}$ & $\begin{array}{l}-2320.266 \\
(\mathrm{p}=.250)\end{array}$ & 0.818 & $11 \% / 7 \% / 8 \% / 34 \% / 10 \% / 31 \%$ \\
\hline 7 & 5402.654 & 4939.582 & $\begin{array}{c}35.723 \\
(p=.760)\end{array}$ & $\begin{array}{l}-2299.399 \\
(\mathrm{p}=.286)\end{array}$ & 0.795 & $\begin{array}{c}11 \% / 17 \% / 4 \% / 8 \% / 22 \% / 9 \% / \\
29 \%\end{array}$ \\
\hline
\end{tabular}

Note. $\mathrm{BIC}=$ Bayesian information criterion; aBIC $=$ sample size adjusted BIC $; \mathrm{LMR}=$ likelihood ratio test ; BLRT $=$ bootstrapped LMR. 
Table 4. Conditional Probabilities ${ }^{\mathrm{a}}$ for Categories of Change Among Latent Groups

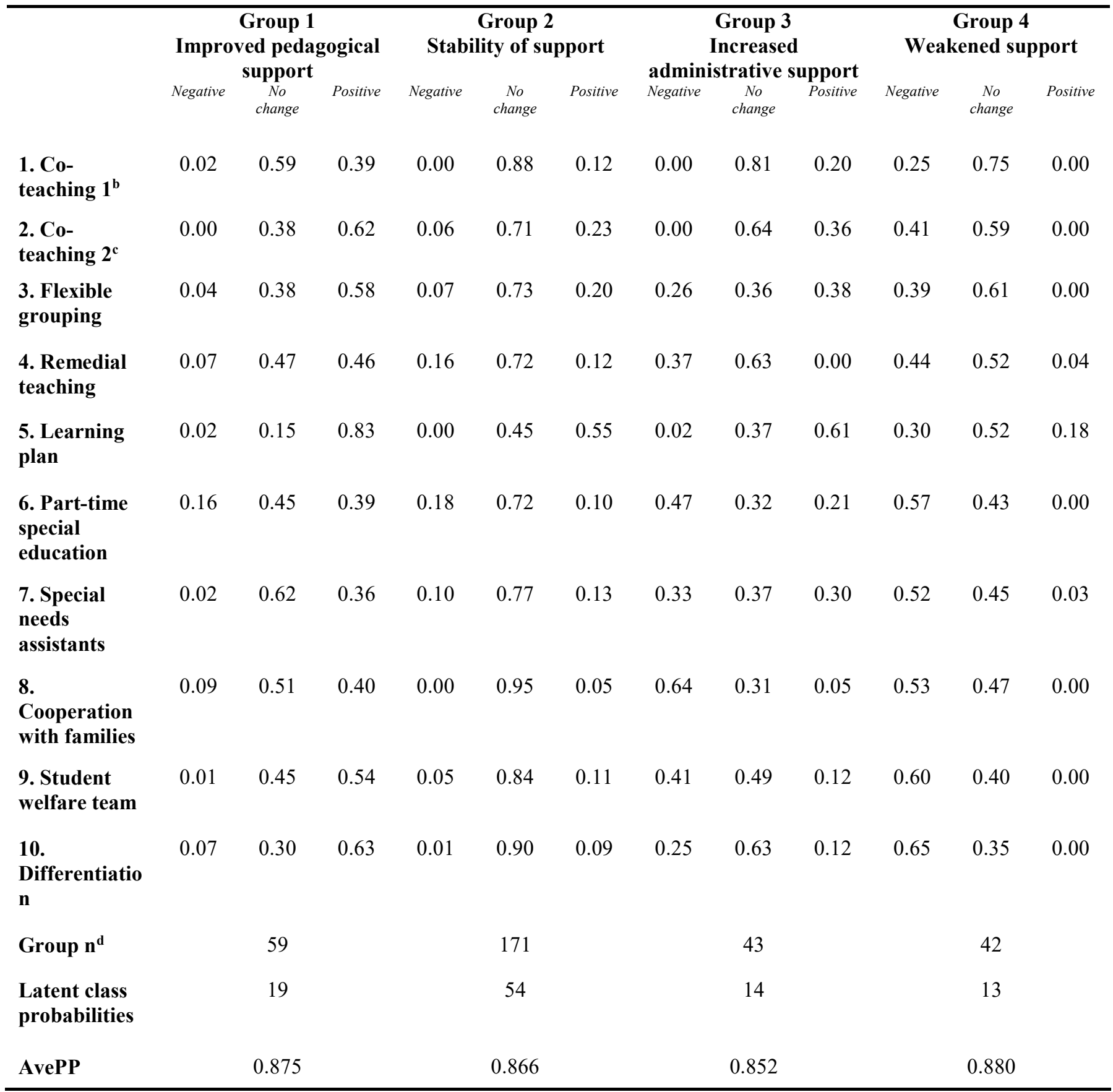

Note. AvePP = average posterior probability. ${ }^{\mathrm{a} C o n d i t i o n a l ~ p r o b a b i l i t i e s ~ a r e ~ d i s t r i b u t i o n s ~ o f ~ t h e ~}$ indicator variables in a given latent group. ${ }^{\mathrm{b}} \mathrm{Classroom}$ teachers or subjects teachers are coteaching together. ${ }^{\mathrm{c}} \mathrm{A}$ special education teacher is co-teaching with a class teacher or a subject teacher. ${ }^{\mathrm{d}}$ Values based on individuals' most likely latent group membership. 
Table 5. Multinomial Regression Analyses for the Assessment of Change

\begin{tabular}{|c|c|c|c|c|c|c|}
\hline & \multicolumn{3}{|c|}{ Group 4 (Ref.) } & \multicolumn{2}{|c|}{ Group 1 (Ref.) } & \multirow{2}{*}{$\begin{array}{l}\text { Group } 2 \text { (Ref.) } \\
\text { Group } 3\end{array}$} \\
\hline & Group 1 & Group 2 & Group 3 & Group 2 & Group 3 & \\
\hline & $\begin{array}{l}\text { OR } \\
{[95 \% \mathrm{CI}]}\end{array}$ & $\begin{array}{l}\text { OR } \\
{[95 \% \mathrm{CI}]}\end{array}$ & $\begin{array}{l}\text { OR } \\
{[95 \% \mathrm{CI}]}\end{array}$ & $\begin{array}{l}\text { OR } \\
{[95 \% \mathrm{CI}]}\end{array}$ & $\begin{array}{l}\text { OR } \\
{[95 \% \mathrm{CI}]}\end{array}$ & $\begin{array}{l}\text { OR } \\
{[95 \% \mathrm{CI}]}\end{array}$ \\
\hline \multicolumn{7}{|l|}{ Individual level } \\
\hline $\begin{array}{l}\text { Work experience as a } \\
\text { principal (year) }\end{array}$ & $\begin{array}{l}0.96 \\
{[0.89,1.02]}\end{array}$ & $\begin{array}{l}1.02 \\
{[0.96,1.07]}\end{array}$ & $\begin{array}{l}1.00 \\
{[0.93,1.07]}\end{array}$ & $\begin{array}{l}1.07 * \\
{[1.01,1.13]}\end{array}$ & $\begin{array}{l}1.04 \\
{[0.97,1.12]}\end{array}$ & $\begin{array}{l}0.98 \\
{[0.93,1.03]}\end{array}$ \\
\hline \multicolumn{7}{|l|}{$\begin{array}{l}\text { Work experience in special } \\
\text { education } \\
\text { No (Ref.) }\end{array}$} \\
\hline Yes & $\begin{array}{l}2.38 \\
{[0.79,7.15]}\end{array}$ & $\begin{array}{l}1.38 \\
{[0.49,3.86]}\end{array}$ & $\begin{array}{l}2.46 \\
{[0.67,9.01]}\end{array}$ & $\begin{array}{l}0.58 \\
{[0.26,1.26]}\end{array}$ & $\begin{array}{l}1.04 \\
{[0.38,2.83]}\end{array}$ & $\begin{array}{l}1.79 \\
{[0.73,4.36]}\end{array}$ \\
\hline \multicolumn{7}{|l|}{$\begin{array}{l}\text { Participation in training } \\
\text { concerning support for } \\
\text { learning and schooling } \\
\text { No (Ref.) }\end{array}$} \\
\hline Yes & $\begin{array}{l}7.25 \\
{[0.96,54,59]} \\
\end{array}$ & $\begin{array}{l}3.23 \\
{[0.96,10.90]} \\
\end{array}$ & $\begin{array}{l}2.05 \\
{[0.40,10.53]} \\
\end{array}$ & $\begin{array}{l}0.45 \\
{[0.06,3.54]} \\
\end{array}$ & $\begin{array}{l}0.28 \\
{[0.03,2.93]} \\
\end{array}$ & $\begin{array}{l}0.63 \\
{[0.14,2.88]} \\
\end{array}$ \\
\hline \multicolumn{7}{|l|}{ School level } \\
\hline \multicolumn{7}{|l|}{$\begin{array}{l}\text { School size } \\
\text { Amount of students at least } \\
200 \text { (Ref.) }\end{array}$} \\
\hline $\begin{array}{l}\text { Amount of students less than } \\
200\end{array}$ & $\begin{array}{l}0.14 * * \\
{[0.04,0.53]}\end{array}$ & $\begin{array}{l}0.38 \\
{[0.12,1.19]}\end{array}$ & $\begin{array}{l}0.41 \\
{[0.09,1.95]}\end{array}$ & $\begin{array}{l}2.72 * \\
{[1.02,7.29]}\end{array}$ & $\begin{array}{l}2.94 \\
{[0.77,11.23]}\end{array}$ & $\begin{array}{l}1.08 \\
{[0.38,3.12]}\end{array}$ \\
\hline \multicolumn{7}{|l|}{$\begin{array}{l}\text { Grade } \\
\text { Grades 1-6 (Ref.) }\end{array}$} \\
\hline Grades 7-9 & $\begin{array}{l}0.95 \\
{[0.16,5.79]}\end{array}$ & $\begin{array}{l}1.33 \\
{[0.29,6.19]}\end{array}$ & $\begin{array}{l}2.00 \\
{[0.29,14.04]}\end{array}$ & $\begin{array}{l}1.39 \\
{[0.40,4.91]}\end{array}$ & $\begin{array}{l}2.10 \\
{[0.42,10.47]}\end{array}$ & $\begin{array}{l}1.50 \\
{[0.42,5.33]}\end{array}$ \\
\hline Grades 1-9 & $\begin{array}{l}3.73 \\
{[0.42,33.33]}\end{array}$ & $\begin{array}{l}3.20 \\
{[0.38,27.12]}\end{array}$ & $\begin{array}{l}5.03 \\
{[0.41,62.40]}\end{array}$ & $\begin{array}{l}0.86 \\
{[0.33,2.20]}\end{array}$ & $\begin{array}{l}1.35 \\
{[0.36,5.03]}\end{array}$ & $\begin{array}{l}1.57 \\
{[0.46,5.34]}\end{array}$ \\
\hline
\end{tabular}




\begin{tabular}{|c|c|c|c|c|c|c|}
\hline $\begin{array}{l}\text { Participating in the initiative } \\
\text { Action to Develop Intensified } \\
\text { and Special Support } \\
\text { No (Ref.) } \\
\text { Yes }\end{array}$ & $\begin{array}{l}1.68 \\
{[0.50,5.59]}\end{array}$ & $\begin{array}{l}2.16 \\
{[0.80,5.86]}\end{array}$ & $\begin{array}{l}1.42 \\
{[0.33,6.14]}\end{array}$ & $\begin{array}{l}1.29 \\
{[0.43,3.86]}\end{array}$ & $\begin{array}{l}0.85 \\
{[0.23,3.17]}\end{array}$ & $\begin{array}{l}0.66 \\
{[0.19,2.23]}\end{array}$ \\
\hline \multicolumn{7}{|l|}{$\begin{array}{l}\text { Principal's assessment of the } \\
\text { school's resources for special } \\
\text { education } \\
\text { More resources are not } \\
\text { needed (Ref.) }\end{array}$} \\
\hline \multicolumn{7}{|l|}{ Municipal level } \\
\hline \multicolumn{7}{|l|}{ Region } \\
\hline Southern Finland & $\begin{array}{l}1.86 \\
{[0.30,11.72]}\end{array}$ & $\begin{array}{l}3.38 \\
{[0.56,20.28]}\end{array}$ & $\begin{array}{l}0.92 \\
{[0.10,8.44]}\end{array}$ & $\begin{array}{l}1.81 \\
{[0.37,8.84]}\end{array}$ & $\begin{array}{l}0.49 \\
{[0.08,3.20]}\end{array}$ & $\begin{array}{l}0.27 \\
{[0.04,1.72]}\end{array}$ \\
\hline South-Western Finland & $\begin{array}{l}1.69 \\
{[0.21,13.52]}\end{array}$ & $\begin{array}{l}3.50 \\
{[0.50,24.37]}\end{array}$ & $\begin{array}{l}1.15 \\
{[0.08,17.23]}\end{array}$ & $\begin{array}{l}2.08 \\
{[0.34,12.79]}\end{array}$ & $\begin{array}{l}0.68 \\
{[0.06,8.03]}\end{array}$ & $\begin{array}{l}0.33 \\
{[0.03,3.25]}\end{array}$ \\
\hline Eastern Finland & $\begin{array}{l}8.30 \\
{[0.16,419.86]}\end{array}$ & $\begin{array}{l}11.79 \\
{[0.23,591.75]}\end{array}$ & $\begin{array}{l}10.97 \\
{[0.12,1010.99]}\end{array}$ & $\begin{array}{l}1.42 \\
{[0.22,9.34]}\end{array}$ & $\begin{array}{l}1.32 \\
{[0.14,12.52]}\end{array}$ & $\begin{array}{l}0.93 \\
{[0.12,7.30]}\end{array}$ \\
\hline Western and Inland Finland & $\begin{array}{l}0.61 \\
{[0.09,4.11]}\end{array}$ & $\begin{array}{l}2.44 \\
{[0.41,14.34]}\end{array}$ & $\begin{array}{l}0.99 \\
{[0.10,9.61]}\end{array}$ & $\begin{array}{l}3.99 \\
{[0.75,21.18]}\end{array}$ & $\begin{array}{l}1.62 \\
{[0.22,12.16]}\end{array}$ & $\begin{array}{l}0.40 \\
{[0.06,2.53]}\end{array}$ \\
\hline Northern Finland & $\begin{array}{l}0.46 \\
{[0.04,5.57]}\end{array}$ & $\begin{array}{l}5.69 \\
{[0.84,38.29]}\end{array}$ & $\begin{array}{l}3.12 \\
{[0.27,36.55]}\end{array}$ & $\begin{array}{l}12.37 * \\
{[1.32,116.20]}\end{array}$ & $\begin{array}{l}6.79 \\
{[0.52,89.25]}\end{array}$ & $\begin{array}{l}0.55 \\
{[0.08,3.98]}\end{array}$ \\
\hline \multicolumn{7}{|l|}{$\begin{array}{l}\text { Population } \\
50000-(\text { Ref.) }\end{array}$} \\
\hline $10000-49999$ & $\begin{array}{l}0.78 \\
{[0.18,3.41]}\end{array}$ & $\begin{array}{l}0.78 \\
{[0.21,2.83]}\end{array}$ & $\begin{array}{l}0.55 \\
{[0.08,3.60]}\end{array}$ & $\begin{array}{l}1.00 \\
{[0.34,2.94]}\end{array}$ & $\begin{array}{l}0.70 \\
{[0.15,3.35]}\end{array}$ & $\begin{array}{l}0.71 \\
{[0.19,2.58]}\end{array}$ \\
\hline 0-9999 & $\begin{array}{l}0.68 \\
{[0.16,2.95]}\end{array}$ & $\begin{array}{l}0.44 \\
{[0.12,1.57]}\end{array}$ & $\begin{array}{l}0.58 \\
{[0.09,3.58]}\end{array}$ & $\begin{array}{l}0.65 \\
{[0.21,2.00]}\end{array}$ & $\begin{array}{l}0.85 \\
{[0.18,4.13]}\end{array}$ & $\begin{array}{l}1.31 \\
{[0.35,4.85]}\end{array}$ \\
\hline
\end{tabular}

Note. Group 1 = Improved pedagogical support; Group 2 = Stability of support; Group 3 = Increased administrative support; Group 4 =

Weakened support; $\mathrm{OR}=$ odds ratio; $\mathrm{CI}=$ confidence interval.

$* p<.05 . * * p<.01$. 